\title{
THE APPLICATION OF TAM FOR INVESTIGATING USERS' ATTITUDE TOWARDS IOT USAGE IN THE UNIVERSITY LIBRARIES OF ODISHA
}

\author{
Dr. Sanghamitra Dalbehera \\ Librarian, Institute of Technical Education \& Research (I.T.E.R), \\ S.O.A University,Bhubaneswar
}

\begin{abstract}
Now-a-days libraries are facing many service challenges which are related to massive quantities of data and direct availability of networked information landscape to develop and explore next generation catalogue and library as a place etc. The collaboration of several of these challenges are associated with scattered technologies within libraries is known as Internet of Things (IoT). IoT is described as a global network infrastructure linking physical and virtual objects through the exploitation of data capture and communication capabilities. These will be characterized by a high degree of autonomous data capture, event transfer, network connectivity and interoperability. The basic set of technologies associated with IoT are Radio Frequency Identification Device(RFID), Wireless communication devices, sensors, cloud computing technologies, energy harvesting technologies and advanced Internet protocol(IPv6). To improve the efficiency and the visibility of library collection and management services, RFID, Wi-Fi and cloud computing technology has emerged as a critical component of IoT system. The purpose of this study is to examine the factors that influence the use of IoT systems such as RFID, Cloud computing system in the library context by adopting the framework of Technology Acceptance Model (TAM). So this paper examines the role of two aspects of IoT implementation in the library services. First, the external variables such as Organizational Competency, Technological Factor, Personal Competency and Environmental Factors and second is the TAM variables such as Perceived Use, Perceived Ease of Use, Behavioral Intension and Attitude towards the use of IoT technology in library system. Total 611 samples from different categories of users from different university libraries of Odisha state have collected for the survey. Based on this sample, this paper analyzes the TAM model in predicting the effects of external variables on TAM variables and also the behavioral intension of the users to adopt IoT in libraries.
\end{abstract}

Keywords: Internet of Thing, TAM, RFID, Cloud computing, University libraries, Perceived Use, Perceived ease of use, Attitude 
Cite this Article: Dr. Sanghamitra Dalbehera, The Application of Tam for Investigating Users' Attitude towards Iot usage in the University Libraries of Odisha. International Journal of Library \& Information Science, 7(5), 2018, pp. 1-26. http://iaeme.com/Home/issue/IJLIS?Volume=7\&Issue $=5$

\section{INTRODUCTION}

The concept of IoT was first coined by Auto-ID Centre at Massachusetts Institute of Technology (MIT) in 1999. According to Cluster of European Research Projects on Internet of Things (CERP-IoT 2009)"Internet of Thing (IoT) is an integrated part of future internet and is defined as a dynamic global network infrastructure with self-configuring capabilities based on standard and interoperable communication protocols where physical and virtual 'things' have identities, physical attributes, virtual personalities and use intelligent interfaces which are seamlessly integrated into the information network.". As the online access to library resources and services is growing, so the emergence of IoT implementation in the University libraries is developing attention. A survey conducted by OCLC(2015),most libraries are trying to identify potential applications for IoT technologies which are mostly related to intelligent use of space and facilities .Such services require the implementation of Radio Frequency Identification(RFID) tags, Wi-Fi and cloud computing to discover more efficient library services and unique identification of library services. Therefore there is a need to understand users' acceptance of IoT technology in the library context and identify the factors that influence their intension to use these technologies described above. For this a user acceptance model known as Technology Acceptance model (TAM) is used in this study.

\section{IMPACT OF IOT TECHNOLOGY IN UNIVERSITY LIBRARIES OF ODISHA}

The basic set of technologies associated with IoT include Radio Frequency Identification Device, infrared sensors, Global Positioning System(GPS),Geographic Information System(GIS), laser scanners, energy harvesting technologies, advanced internet protocol, wireless communication devices, cloud computing and other information sensing device. These smart technologies help in enhancing the power of network and enable smallest objects with a capacity to connect and interact. The architecture of IoT is divided into three basic layers: - i) Perception Layer: - It is known as sensor layer and implemented as the bottom layer in IoT architecture. The perception layer interacts with physical devices and components through smart devices. One application of this layer is RFID based circulation system in libraries. ii)Network Layer: -It is also known as the transmission layer and implemented as the middle layer in IoT architecture. Various devices such as hub, switching and gateway as well as various communication technologies such as Bluetooth, Wi-Fi and magic mirror are integrated in this layer. One implementation of this layer in library sector is cloud computing which has virtually unlimited capabilities in terms of storage and processing power and are highly scalable and managed on demand infrastructure e.g. server, storage, network and on demand software e.g. application, middleware management and development tools. iii) Application Layer: -It is also known as the business layer and implemented as the top layer in IoT architecture. Its implementation in libraries is through Pressure Pad sensor which consists of a thin sheet sensor pad with Wi-Fi technology connected to processing unit which record and controls the system. Another implementation of application layer in library field is Magic mirror which is able to sense what titles a library is holding and recommend similar like materials, events, review of the contents, facial recognition and give a sneak peak into the books. Above mentioned technologies are inter linked to improve service efficiency and making academic library as a smart library. 


\section{REVIEW OF LITERATURE}

According to Atzori et.al.(2010), Sterling(2005) and Internet Reports(2005), Internet of Thing(IoT) refers to the stringent connectedness between digital and physical world. Kranenburg(2008) described IoT as a dynamic global network infrastructure with selfconfiguring capabilities based on standard and interoperable communication protocols where physical and virtual 'Things' have identities, physical attributes and virtual personalities and use intelligent interfaces. An IoT system is comprised of a number of functional blocks to facilitate various utilities to the system such as sensing, identification, actuation, communication and management; Sebastian and Ray (2015) Ayre (2005) mentioned that, Singapore Public Library began using RFID as a substitute for the electro-magnetic and barcoding systems in 1998. In a typical RFID system, the radio waves are generated, modulated, amplified and then transmitted by a radio frequency transmitter through an antenna. These radio waves in turn are received and processed by the RFID tags which send back a unique identification code and other data via radio waves; Ampatzidis and Vougioukas(2009). Cunningham (2010) analyzed the implementation of RFID at the Pilkington Library and concluded that issue and return of documents were surpassed within three months and staffing costs were reduced. According to Dwivedi et al.(2013),"In the library context, the RFID tags are embedded within the objects like books, journals ,DVDs etc. and the receiver is integrated within various systems such as the self-checkout system, the security system and the inventory management system". Madhusudan (2010) explored the use and implementation of RFID technology at the Indian Law institute library and National Social Science Documentation Centre Library, Delhi and found that the implementation of RFID technology in libraries increased the transaction speed and the utilization of library services. Miller (2008) and Sultan (2010) described cloud computing as a new trend in developing and delivering IT infrastructure, platform, and software solutions to organizations as well as to individuals. Yang (2012) depicted that "The cloud-based new generation of ILS allows many libraries to share useful data like sharing of full-text journal titles from electronic databases, many libraries subscribe to the same database". According to Davis \&Venkatesh(2000) "The goal of TAM is to provide an explanation of the determinants of computer acceptance that is general, capable of explaining user behavior across a broad range of end-user computing technologies and user populations". Tan and Teo (2000), Chen, Lin, Yeh \& Lou (2013) considered that perceived usefulness and perceived ease of use are the two imperative determinants in explaining the adoption of technology innovation in TAM. In this model, both these factors are influenced by external factors; Park, Son \& Kim(2012) ,AlAmmary, Al-Sherooqi \& Al-Sherooqi(2014). According to Emmett(2011); Davis, Bagozzi \& Warshaw(1989); Liu, Chen, Sun, Wible \& Kuo(2010), the external factors play a vital role in explaining technology adoption behavior. Top management as one of the external factor can provide a vision and commitment to create a positive environment for innovation; Lee and Kim (2007) \& Pyke(2009). Dholakia and Kshetri (2004); Hong and Zhu(2006) \& Pan and $\operatorname{Jang}(2008)$ found that the size of a firm is one of the major determinants of IT innovation. Another external factor known as, Technological readiness of an organization means technological infrastructure and IT human resources influences the adoption of new technology; Kuan and Chau(2001); Wang et al.(2010) \& Zhu et al.(2006. Empirical research demonstrated that persons with a higher level of domain knowledge were able to conduct searches and database queries more efficiently and more rapidly than novices; Marchonini et al. (1993) \& Thong et al. (2002). Ajzen (2001) described that "Attitude partially mediate the impact of PU on behavioral intension by explaining the difficulties of capturing attitude towards a behavior within a context accurately". 


\section{THEORETICAL BASIS AND THE PROPOSED CONCEPTUAL MODEL}

\subsection{Theoretical framework}

Various theoretical models have been developed to investigate and explore the construct of users' behavior toward the adoption of information technology. Technology Acceptance Model (TAM) is one of the user acceptance model which proposes that technological innovation adoption is influenced by endogenous or TAM variables as well as exogenous or external variables. Some of these variables are described below:-

\subsubsection{TAM variables}

i. Perceived Usefulness (PU): -It is defined as the degree to which a person believes that using a specific application system will increase his/her job performance within an organizational context.

ii. Perceived Ease of Use (PEU): -PEU is defined as "the degree to which a person believes that using a particular system would be free from effort".

iii. Attitude towards Usage (ATU): -Attitude towards usage refers to the degree to which an individual evaluates and associates the IoT based library systems with his /her job.

iv. Behavioral Intension (BI): -It is a measure of the strength of one's intention to perform a specified behavior.

v. Actual use of IoT (AU):-Actual system use is a measure of the spread of the technology. It is a frequency and duration of using new technology.

\subsubsection{External Variables}

In this study four categories of external factors i.e. organizational competency, technological factor, personal competency and environmental factors are considered which are important in the adoption of IoT in libraries of Odisha.

i. Organizational Competency $(\mathrm{OC})$ is defined as the willingness of an organization to try out any new information technology. It consists of resources and characteristics of the firm. In this study the organizational competency is composed of three main components such as Top Management Support, Firm size and Technological Readiness.

ii. Technological Factors (TF) refers to the internal and external technologies that an organization can use in their workflow .For adopting new technologies, variables like System quality, Service quality and Relevance are considered.

iii. Personal Competency (PC) involves the willingness of an individual to try out any new information technology .Learning a person's individual innovativeness will help to understand further how perceptions are found and the subsequent role they play in the formation of individual behavior. It consists of items like Knowledge of Search Domain, Self-efficacy and Experience of the staff.

iv. Environmental Factors (EF means that small environment where the organization runs their firm as well as Technology service providers. The variables include in environmental factors are Competitive Pressure, Security and Collective trust.

\subsection{Proposed Model and Research Hypotheses}

In this study, a research model has been developed to evaluate the factors that influence the intention of using IoT in library services that combines the variables found in the technology 
acceptance model(TAM) with other external variables such as Organizational competency, Technological factors, Personal competency and Environmental factors. Fig (1) illustrates a framework of nine important factors which are expected to affect behavioral intention as well as actual system usage to the adoption of the IoT in library services.

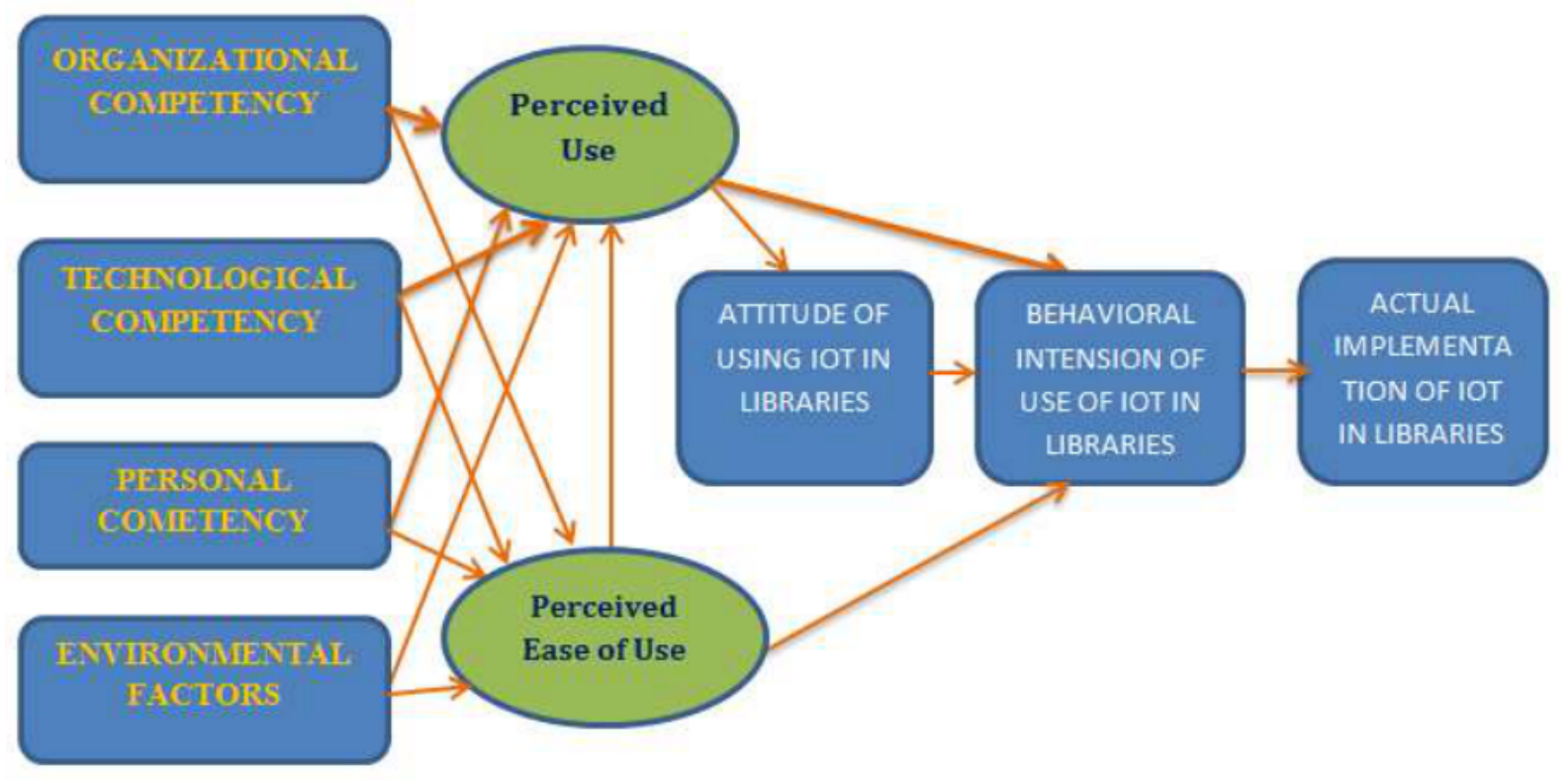

Figure 1 Proposed Research Model

\subsubsection{Research Hypothesis}

Based on the proposed research model, the following hypotheses are established:

H1a: Organizational Competency has a significant influence on perceived usefulness for the usage of IOT in libraries.

H1b: Organizational Competency has a significant influence on perceived ease of use for the usage of IOT in libraries

H2a: Technological Factor has a positive effect on perceived usefulness for the implementation of IoT in libraries.

$\boldsymbol{H} \boldsymbol{2 b}$ : Technology Factor has a positive effect on perceived ease of use for the implementation of IoT in libraries.

H3a: The Personal Competency of the users has a significant effect on the perceived usefulness for the usage of IOT in libraries.

$\boldsymbol{H} \mathbf{3} \boldsymbol{b}$ : The personal Competency of users has a significant effect the perceived ease of use for the usage of IOT in libraries.

H4a: The Environmental Factors has a positive influence on perceived usefulness for the adoption of IoT in libraries.

H4b: The Environmental Factor has a positive impact on perceived ease of use for the adoption of IoT in libraries.

H5a: Perceived usefulness significantly influences on the attitude of users towards the acceptance of the IOT systems in libraries.

H5b: Perceived usefulness significantly influences the behavioral intension of users towards the acceptance of the IOT technology in libraries. 
The Application of Tam for Investigating Users' Attitude towards Iot usage in the University Libraries of Odisha

H6a: Perceived ease of use will positively influence the perceived usefulness of the IOT based systems in libraries.

H6b: Perceived ease of use will positively influence the behavioral intension of the users towards the acceptance of IOT technology in libraries.

H7: Attitude will significantly influence the behavioral intension of users towards the use of the IOT systems in libraries.

H8: Behavioral intension has a significant impact on the actual implementation of IOT technology in libraries.

\section{OBJECTIVES}

The main aim of this study is to draw the constructs of TAM model to find out whether it can be applied to the current adoption of IoT technologies in the University libraries of Odisha. The objectives for this study are given below:-

1. To determine the factors responsible for the adoption of IoT technology in the University libraries of Odisha.

2. To develop an adoption model by using TAM which will be used to study different external variables that have significant effects through the TAM framework on library users intention to adopt IoT technology in libraries of Odisha.

3. To assess the impact of organizational, technological, personal and environmental factors on the adoption of IoT technology.

4. To find whether perceived usefulness influences the attitude of using IoT in the University libraries of Odisha.

5. To find whether perceived ease of use influences the behavioral intensions of the users on the adoption of IoT in the libraries of Odisha.

6. To assess the influence of independent variables on the external factors in the proposed TAM model.

7. To examine the users' perception for the use of IoT technology such as RFID, Cloud computing and $\mathrm{Wi}-\mathrm{Fi}$ in these libraries of Odisha.

8. To provide essential recommendations for the librarians to make adoption of IoT more successful in the University libraries of Odisha.

\section{RESEARCH METHODOLOGY AND DATA ANALYSIS}

\subsection{Data collection and Sample}

There are 21 universities established in different parts of Odisha state out of which 12 are Govt., 10 are private and two are deemed/deemed to be university.Table- 1 shows the name of the studied universities and their year of establishment in Odisha. A questionnaire survey was used for collection of data from a purposive sample of 870 library users such as faculty, research scholars, students and also the library professionals drawn from these university libraries of Odisha. Finally, 611(70.02\%) valid questionnaire were selected for data analysis and interpretation. Table- 2 shows the status of the respondents for this study purpose. The data collected were interpreted, classified and transferred into coded form, entered into Microsoft Excel and transferred in Statistical Package for Social Sciences (SPSS). 
Dr. Sanghamitra Dalbehera

Table 1 List of Participating University Libraries of Odisha

\begin{tabular}{|c|c|c|c|c|}
\hline $\begin{array}{c}\text { SI.N } \\
\mathbf{0}\end{array}$ & $\begin{array}{l}\text { Name of the } \\
\text { University }\end{array}$ & $\begin{array}{c}\text { Year of } \\
\text { Establishmen } \\
t\end{array}$ & URL & Category \\
\hline 1. & Utkal University & 1943 & www.utkaluniv.org.in & Govt. \\
\hline 2. & $\begin{array}{l}\text { Sambalpur } \\
\text { University }\end{array}$ & 1967 & http://www.suniv.ac.in/ & Govt. \\
\hline 3. & $\begin{array}{l}\text { Berhampur } \\
\text { University }\end{array}$ & 1967 & http://www.buodisha.edu.in/ & Govt. \\
\hline 4. & $\begin{array}{c}\text { Orissa University of } \\
\text { Agriculture \& } \\
\text { Technology }\end{array}$ & 1962 & http://www.ouat.nic.in/ & Govt. \\
\hline 5. & $\begin{array}{c}\text { Fakir Mohan } \\
\text { University, Balasore }\end{array}$ & 1999 & http://www.fmuniversity.nic.in/ & Govt. \\
\hline 6. & $\begin{array}{c}\text { National Law } \\
\text { University, Cuttack }\end{array}$ & 2008 & http://www.nluo.ac.in/ & Govt. \\
\hline 7. & $\begin{array}{c}\text { Ravenshaw } \\
\text { University, Cuttack }\end{array}$ & 1868 & $\frac{\text { http://www.ravenshawuniversity.ac. } \mathrm{i}}{\mathrm{n} /}$ & Govt. \\
\hline 8. & $\begin{array}{l}\text { Khallikote } \\
\text { University, } \\
\text { Berhampur }\end{array}$ & 2015 & http://khallikoteuniversity.ac.in/ & Govt. \\
\hline 9. & $\begin{array}{c}\text { North Odisha } \\
\text { University, Baripada }\end{array}$ & 1999 & http://www.nou.nic.in/ & Govt. \\
\hline 10. & $\begin{array}{l}\text { Central University of } \\
\text { Odisha, Koraput }\end{array}$ & 2009 & http://cuo.ac.in/ & Govt. \\
\hline 11. & $\begin{array}{c}\text { ShriJagannath } \\
\text { Sanskrit University, } \\
\text { Puri } \\
\end{array}$ & 1981 & http://www.sjsv.nic.in/ & Govt. \\
\hline 12. & $\begin{array}{c}\text { Sikha 'o' } \\
\text { Anusandhan Deemed } \\
\text { to be University }\end{array}$ & 2007 & http://www.soa.ac.in/ & $\begin{array}{l}\text { Deemed to } \\
\text { be }\end{array}$ \\
\hline 13. & $\begin{array}{l}\text { Veer SurendraSai } \\
\text { University of } \\
\text { Technology(VSSUT } \\
\text { ), Burla, Sambalpur }\end{array}$ & 1956 & http://www.vssut.ac.in/ & $\begin{array}{l}\text { State } \\
\text { Technologica } \\
\text { 1 University }\end{array}$ \\
\hline 14 & BPUT University & 2002 & http://www.bput.ac.in/ & $\begin{array}{c}\text { State } \\
\text { Technologica } \\
\text { 1 University } \\
\end{array}$ \\
\hline 15. & $\begin{array}{c}\text { Kalinga Institute of } \\
\text { Technology(KIIT) } \\
\text { University }\end{array}$ & 2004 & http://kiit.ac.in/ & $\begin{array}{l}\text { Deemed to } \\
\text { be }\end{array}$ \\
\hline 16. & $\begin{array}{c}\text { Centurian University } \\
\text { of Technology \& } \\
\text { Management, } \\
\text { Bhubaneswar }\end{array}$ & 2010 & https://www.cutm.ac.in/ & Private \\
\hline 17. & $\begin{array}{l}\text { Xavier University, } \\
\text { Bhubaneswar }\end{array}$ & 2013, & https://www.xub.edu.in/ & Private \\
\hline 18. & $\begin{array}{l}\text { Utkal University of } \\
\text { Culture }\end{array}$ & 1999, & http://uuc.ac.in/ & Govt. \\
\hline 19. & Rama Devi Women's & 2015 & http://www.rdwuniversity.nic.in/ & Govt. \\
\hline
\end{tabular}


The Application of Tam for Investigating Users' Attitude towards Iot usage in the University Libraries of Odisha

\begin{tabular}{|c|c|c|c|c|}
\hline & University & & & \\
\hline 20. & $\begin{array}{c}\text { GangadharMeher } \\
\text { University }\end{array}$ & 2015 & http://www.gmuniversity.ac.in/ & Govt. \\
\hline
\end{tabular}

Table 2 Status of the Respondents

\begin{tabular}{|c|c|c|c|c|}
\hline University & $\begin{array}{c}\text { Sample } \\
\text { population }\end{array}$ & $\begin{array}{c}\text { No. of questionnaires } \\
\text { distributed }\end{array}$ & $\begin{array}{c}\text { Questionnaires } \\
\text { Received }\end{array}$ & Percentage(\%) \\
\hline Govt. & 404 & 260 & 176 & 67.69 \\
\hline Private & 426 & 357 & 250 & 70.02 \\
\hline Deemed to be & 376 & 253 & 185 & 73.12 \\
\hline Total & 1206 & 870 & 611 & 70.22 \\
\hline
\end{tabular}

As shown in table-2, the respondents from Govt. college libraries are of $67.69 \%$ where as $70.02 \%$ are from private university libraries and the respondents from deemed university libraries are around $73.12 \%$.The total percentage of respondents out of 870 is $70.22 \%$.

\subsection{Questionnaire Design}

This study is quantitatively focused on to examine the usage of IoT in libraries by University faculties, research scholars and students for the academic purposes using TAM. The questionnaire comprised of 17 questions in total, all of which were designed to be multiple choice questions, aimed at investigating the respondents' perception .The respondents were asked to rate their agreement on each statement using a 1-5 Likert scale, where one indicated strongly disagree and five indicated strongly agree.

\section{ANALYSIS OF THE RESULT}

The collected data are analyzed and interpreted which are presented below:

\subsection{Demographic Characteristics}

Table-3 presents the demographic factors of the respondents of this survey. The statistics of the sample shows that in the category of users the students consists of highest percentage $(46.15 \%)$ followed by the library professionals $(20.45 \%)$ while the faculty and research scholars obtain $17.68 \%$ and $15.71 \%$ respectively .Similarly the users are more in Engineering discipline (39.44\%) followed by the Medical science $(23.73 \%)$. The respondents from social science and management are low i.e. $21.11 \%$ and $15.71 \%$ respectively. The frequency distribution of status of the respondents shows that 385 out of 611 of the respondents are male (63\%) while female respondents are 226(36.99\%).

Table 3 Demographic characteristics of the respondents

\begin{tabular}{|c|c|c|c|}
\hline Demographic variables & & Frequency & $\begin{array}{c}\text { Percentage } \\
\mathbf{( \% )}\end{array}$ \\
\hline \multirow{3}{*}{ Types of Users } & Faculty & 108 & 17.68 \\
\cline { 2 - 4 } & Research scholar & 96 & 15.71 \\
\cline { 2 - 4 } & Student & 282 & 46.15 \\
\cline { 2 - 4 } & Library professional & 125 & 20.45 \\
\hline & Total & 611 & 99.99 \\
\hline Discipline & Engineering & 241 & 39.44 \\
\hline & Medical science & 145 & 23.73 \\
\hline & Social science & 96 & 21.11 \\
\hline & Management & 15.71 \\
\hline
\end{tabular}


Dr. Sanghamitra Dalbehera

\begin{tabular}{|c|c|c|c|}
\hline & Total & 611 & 99.99 \\
\hline \multirow{3}{*}{ Gender } & Male & 385 & 63 \\
\hline & Female & 226 & 36.99 \\
\hline & Total & 611 & 99.99 \\
\hline \multirow[t]{7}{*}{ Age Group } & $<21$ & 178 & 29.14 \\
\hline & $21-30$ & 265 & 43.37 \\
\hline & $31-40$ & 93 & 15.22 \\
\hline & $41-50$ & 44 & 7.20 \\
\hline & $51-60$ & 26 & 4.25 \\
\hline & $>60$ & 5 & 0.82 \\
\hline & Total & 611 & 100 \\
\hline \multirow{6}{*}{ Qualification } & Ph.D. & 59 & 9.65 \\
\hline & Post Graduate & 72 & 11.78 \\
\hline & Bachelor's Degree & 255 & 41.73 \\
\hline & Undergraduate & 137 & 22.42 \\
\hline & Others & 88 & 14.40 \\
\hline & Total & 611 & 99.98 \\
\hline \multirow[t]{7}{*}{ Designation } & Professor & 28 & 12.01 \\
\hline & Asst. Professor & 31 & 13.30 \\
\hline & Associate professor & 12 & 5.15 \\
\hline & Lecturer & 37 & 15.87 \\
\hline & Library Authority & 98 & 42.06 \\
\hline & Others & 27 & 11.58 \\
\hline & Total & 233 & 99.97 \\
\hline \multirow{6}{*}{$\begin{array}{c}\text { Awareness about IOT } \\
\text { Implementation in } \\
\text { libraries }\end{array}$} & I know all about IOT applications in libraries & 126 & 20.62 \\
\hline & I have some knowledge of what it is & 258 & 42.23 \\
\hline & I have only heard about it & 140 & 22.91 \\
\hline & I am not familiar with it at all & 66 & 10.80 \\
\hline & Nil/No response & 21 & 3.43 \\
\hline & Total & 611 & 99.99 \\
\hline \multirow[t]{6}{*}{$\begin{array}{c}\text { Duration in current Job } \\
\text { (year) }\end{array}$} & $<1 \mathrm{yr}$ & 59 & 9.65 \\
\hline & $1-5$ yrs. & 68 & 11.12 \\
\hline & $6-10$ yrs. & 83 & 13.59 \\
\hline & $11-15 \mathrm{v}$ yrs. & 240 & 39.27 \\
\hline & $>15$ yrs. & 161 & 26.35 \\
\hline & Total & 611 & 99.98 \\
\hline
\end{tabular}

The age group " $21-30$ " years old consists of the highest percentage (43.37\%), while ">60yrs." group consists of lowest percentage i.e. 0.82\%. Among the 611 respondents, $41.73 \%$ are Bachelor's degree followed by $22.42 \%$ are undergraduate, $11.78 \%$ are post graduate while $9.65 \%$ are Ph.D. holders. In designation category, we also observe that $42.06 \%$ of respondents were from library authorities, $15.87 \%$ were lecturers followed by $13.30 \%$ are Asst. Professor. Regarding the awareness about IoT implementation in libraries $42.23 \%$ have some knowledge about this followed by $22.91 \%$ have only heard about it, while $20.62 \%$ have known all about IoT application in libraries and $10.80 \%$ does not know anything. The experience of the faculties is highest i.e. $39.27 \%$ in $11-15$ years followed by $26.35 \%$ are having more than 15 years of experience. 
The Application of Tam for Investigating Users' Attitude towards Iot usage in the University Libraries of Odisha

\subsection{Descriptive Analysis}

The measurement model was examined for internal consistency, convergent and discriminant validity. In the first stage, reliability and validity of the model were measured and the hypotheses were tested in the second stage.

\subsubsection{Reliability Test}

In order to measure the internal consistency of the survey items for each of the shortlisted construct used in this study, Cronbach's Alpha test was conducted which is shown in table4.Theses constructs are Organizational competency which includes 8 items; Technological factor consists of 8 items; Personal competency contains 8 variables; Environmental factors includes 7 items; whereas perceived usefulness and perceived ease of use consists of 8 items each; attitude includes 6 variables; behavioral Intension contains 7 items and finally the actual system usage consists of 4 items. All the nine constructs for the sample of 611 respondents shows good values of Cronbach's alpha between 0.77 to 0.89 indicating a relatively higher internal consistency among the items. The cronbach's alphas for the external constructs are above 0.70 thresholds and above 0.80 for all TAM constructs as shown in table- 4 .

Table 4 Cronbach's Alpha results

\begin{tabular}{|c|c|c|c|}
\hline Sl.No & Item/Construct & $\begin{array}{c}\text { No. of } \\
\text { Items }\end{array}$ & $\begin{array}{c}\text { Cronbach } \\
\text { Alpha Value }\end{array}$ \\
\hline 1. & Organizational Competency(OC) & 8 & 0.89 \\
\hline 2. & Technological Factors(TF) & 8 & 0.84 \\
\hline 3. & Environmental Factors(EF) & 7 & 0.87 \\
\hline 4. & Personal Competency(PC) & 8 & 0.76 \\
\hline 5. & Perceived Usefulness(PU) & 8 & 0.82 \\
\hline 6. & Perceived Ease of Use(PEU) & 8 & 0.85 \\
\hline 7. & Attitude towards IOT implementation in \\
libraries(ATI) & 6 & 0.8 \\
\hline 8. & Behavioral Intention for the use of IOT in \\
libraries/applications(BI) & 7 & 0.83 \\
\hline 9. & Actual Use of IOT in libraries(AU) & 4 & 0.87 \\
\hline
\end{tabular}

\subsubsection{Assessing Convergent Validity}

The convergent validity for all the constructs is determined by Average Variance Extracted (AVE), Composite Reliability and construct reliability (CR). In this study, TAM comprised of total nine constructs i.e. four external factors $(\mathrm{OC}, \mathrm{TF}, \mathrm{PC} \& \mathrm{EF})$ and five dependent variables (PU, PEU, ATI, BI and AU). Total 64 items were being measured against nine constructs and each construct had a specific number of items to its account. Table-5 illustrates the descriptive statistics for both the dependent and independent construct used in this study. 
Dr. Sanghamitra Dalbehera

Table 5 Descriptive Statistics of the Constructs and corresponding measured items

\begin{tabular}{|c|c|c|c|c|c|c|}
\hline $\begin{array}{c}\text { LATENT } \\
\text { CONSTRUCTS }\end{array}$ & & ITEMS & $\begin{array}{c}\text { COMPOSITE } \\
\text { RELIABILIT } \\
\text { Y }\end{array}$ & $\begin{array}{c}\text { MEA } \\
\mathbf{N}\end{array}$ & SD & $\begin{array}{c}\text { AVERAGE } \\
\text { VARIANCE } \\
\text { EXTRACTED(AV } \\
\text { E) }\end{array}$ \\
\hline \multirow[t]{6}{*}{$\begin{array}{l}\text { ORGANIZATIONA } \\
\text { L COMPETENCY }\end{array}$} & OC1 & $\begin{array}{c}\text { Top } \\
\text { management } \\
\text { is interested in } \\
\text { using IoT in } \\
\text { library } \\
\text { services in } \\
\text { order to gain } \\
\text { competitive } \\
\text { advantage. }\end{array}$ & 0.864 & 4.76 & $\begin{array}{l}0.6 \\
2\end{array}$ & 0.84 \\
\hline & $\mathrm{OC} 2$ & $\begin{array}{c}\text { Top } \\
\text { management } \\
\text { supports the } \\
\text { implementatio } \\
\text { n of IoT in } \\
\text { libraries. }\end{array}$ & & 4.48 & $\begin{array}{c}0.7 \\
0\end{array}$ & \\
\hline & OC3 & $\begin{array}{c}\text { Top } \\
\text { management } \\
\text { provides } \\
\text { strong } \\
\text { leadership and } \\
\text { engages in the } \\
\text { process when } \\
\text { it comes to } \\
\text { information } \\
\text { systems. }\end{array}$ & & 4.36 & $\begin{array}{l}1.0 \\
3\end{array}$ & \\
\hline & OC4 & $\begin{array}{c}\text { My } \\
\text { organization } \\
\text { has an } \\
\text { intention to } \\
\text { participate in } \\
\text { adopting and } \\
\text { developing } \\
\text { IoT } \\
\text { technology. }\end{array}$ & & 4.69 & $\begin{array}{c}0.9 \\
9\end{array}$ & \\
\hline & OC5 & $\begin{array}{c}\text { Top } \\
\text { management } \\
\text { provides } \\
\text { enough } \\
\text { resources } \\
\text { (hardware and } \\
\text { software) for } \\
\text { IoT } \\
\text { utilization. }\end{array}$ & & 4.79 & $\begin{array}{c}0.9 \\
1\end{array}$ & \\
\hline & OC6 & $\begin{array}{l}\text { My } \\
\text { organization } \\
\text { provides } \\
\text { proper } \\
\text { training for }\end{array}$ & & 4.55 & $\begin{array}{c}0.8 \\
9\end{array}$ & \\
\hline
\end{tabular}


The Application of Tam for Investigating Users' Attitude towards Iot usage in the University Libraries of Odisha

\begin{tabular}{|c|c|c|c|c|c|c|}
\hline & & $\begin{array}{c}\text { IoT } \\
\text { utilization. }\end{array}$ & & & & \\
\hline & OC7 & $\begin{array}{c}\text { Top } \\
\text { management } \\
\text { understands } \\
\text { the } \\
\text { importance of } \\
\text { IoT in } \\
\text { libraries and is } \\
\text { willing to take } \\
\text { risks for its } \\
\text { adoption. }\end{array}$ & & 4.72 & $\begin{array}{c}0.9 \\
1\end{array}$ & \\
\hline & OC8 & $\begin{array}{c}\text { My } \\
\text { organization } \\
\text { does not have } \\
\text { any resistance } \\
\text { to using IoT } \\
\text { tools. }\end{array}$ & & 4.66 & $\begin{array}{c}0.9 \\
8\end{array}$ & \\
\hline & & AVERAGE & & 4.6 & & \\
\hline \multirow[t]{5}{*}{$\begin{array}{l}\text { TECHNOLOGICAL } \\
\text { FACTOR }\end{array}$} & $\mathrm{TF} 1$ & $\begin{array}{c}\text { My } \\
\text { organization } \\
\text { has technical } \\
\text { capability of } \\
\text { using new IoT } \\
\text { technology. }\end{array}$ & 0.88 & 4.74 & $\begin{array}{c}0.6 \\
1\end{array}$ & 0.769 \\
\hline & $\mathrm{TF} 2$ & $\begin{array}{l}\text { The service } \\
\text { level of our } \\
\text { library will } \\
\text { increase with } \\
\text { the } \\
\text { implementatio } \\
\text { n of IoT } \\
\text { technology by } \\
\text { increasing the } \\
\text { level of user } \\
\text { satisfaction }\end{array}$ & & 4.65 & $\begin{array}{c}0.8 \\
3\end{array}$ & \\
\hline & TF3 & $\begin{array}{l}\text { System } \\
\text { content } \\
\text { quality is } \\
\text { timely } \\
\text { updated with } \\
\text { the latest } \\
\text { technology. }\end{array}$ & & 4.94 & $\begin{array}{c}0.8 \\
4\end{array}$ & \\
\hline & $\mathrm{TF} 4$ & $\begin{array}{l}\text { The adoption } \\
\text { of IoT } \\
\text { technology } \\
\text { provides } \\
\text { better service } \\
\text { quality to the } \\
\text { users. }\end{array}$ & & 4.62 & $\begin{array}{l}0.7 \\
8\end{array}$ & \\
\hline & TF5 & $\begin{array}{l}\text { IoT tools that } \\
\text { I use are easy }\end{array}$ & & 4.68 & $\begin{array}{c}0.7 \\
2\end{array}$ & \\
\hline
\end{tabular}




\begin{tabular}{|c|c|c|c|c|c|c|}
\hline & & $\begin{array}{l}\text { for data input } \\
\text { and output. }\end{array}$ & & & & \\
\hline & TF6 & $\begin{array}{l}\text { Output quality } \\
\text { of IoT } \\
\text { utilization } \\
\text { improves } \\
\text { information } \\
\text { accessibility.. }\end{array}$ & & 4.80 & $\begin{array}{c}0.9 \\
3\end{array}$ & \\
\hline & TF7 & $\begin{array}{l}\text { I think IT } \\
\text { resources can } \\
\text { be used more } \\
\text { effectively } \\
\text { with the } \\
\text { adoption of } \\
\text { IoT } \\
\text { technology. }\end{array}$ & & 4.39 & $\begin{array}{c}0.9 \\
1\end{array}$ & \\
\hline & TF8 & $\begin{array}{l}\text { IT costs will } \\
\text { sink by using } \\
\text { IoT } \\
\text { applications. }\end{array}$ & & 4.21 & $\begin{array}{c}0.6 \\
0\end{array}$ & \\
\hline & & AVERAGE & & 4.62 & & \\
\hline \multirow[t]{4}{*}{$\begin{array}{l}\text { ENVIRONMENTA } \\
\text { L FACTOR }\end{array}$} & EF1 & $\begin{array}{l}\text { Using IoT } \\
\text { technology } \\
\text { helps our } \\
\text { organization } \\
\text { to compete } \\
\text { better with our } \\
\text { competitors. }\end{array}$ & 0.766 & 4.59 & $\begin{array}{c}0.8 \\
7\end{array}$ & 0.828 \\
\hline & EF2 & $\begin{array}{l}\text { Overall, I } \\
\text { have control } \\
\text { over my } \\
\text { information } \\
\text { during the use } \\
\text { of the IoT } \\
\text { technology } \\
\text { (such as RFID } \\
\text { \& Cloud } \\
\text { computing). }\end{array}$ & & 5.14 & $\begin{array}{c}0.8 \\
1\end{array}$ & \\
\hline & EF3 & $\begin{array}{l}\text { Security is a } \\
\text { big concern in } \\
\text { using RFID } \\
\text { and cloud } \\
\text { computing } \\
\text { applications. }\end{array}$ & & 4.29 & $\begin{array}{c}0.8 \\
0\end{array}$ & \\
\hline & EF4 & $\begin{array}{l}\text { I trust the } \\
\text { ability of IoT } \\
\text { applications } \\
\text { such as cloud } \\
\text { computing, } \\
\text { RFID and Wi- } \\
\text { Fi in libraries } \\
\text { that would } \\
\text { protect my }\end{array}$ & & 4.64 & $\begin{array}{c}0.7 \\
5\end{array}$ & \\
\hline
\end{tabular}


The Application of Tam for Investigating Users' Attitude towards Iot usage in the University Libraries of Odisha

\begin{tabular}{|c|c|c|c|c|c|c|}
\hline & & privacy. & & & & \\
\hline & EF6 & $\begin{array}{l}\text { The security } \\
\text { issue of } \\
\text { personal } \\
\text { information is } \\
\text { a major } \\
\text { obstacle for } \\
\text { me to use IoT } \\
\text { based } \\
\text { applications in } \\
\text { libraries. }\end{array}$ & & 5.11 & $\begin{array}{c}0.9 \\
4\end{array}$ & \\
\hline & EF7 & $\begin{array}{c}\text { Our } \\
\text { organization } \\
\text { thinks that } \\
\text { using IoT } \\
\text { technology } \\
\text { such as RFID, } \\
\text { Wi-Fi and } \\
\text { cloud } \\
\text { computing are } \\
\text { associated } \\
\text { with high } \\
\text { risks. }\end{array}$ & & 4.82 & $\begin{array}{c}0.9 \\
1\end{array}$ & \\
\hline & & AVERAGE & & 4.08 & & \\
\hline \multirow[t]{4}{*}{$\begin{array}{l}\text { PERSONAL } \\
\text { COMPETENCY }\end{array}$} & PC1 & $\begin{array}{c}\text { I have } \\
\text { technical } \\
\text { skills of using } \\
\text { a new } \\
\text { information } \\
\text { technology. }\end{array}$ & 0.841 & 3.78 & & 0.92 \\
\hline & PC2 & $\begin{array}{l}\text { I can freely } \\
\text { navigate the } \\
\text { contents of the } \\
\text { IoT based } \\
\text { system. }\end{array}$ & & 4.17 & $\begin{array}{l}1.0 \\
7\end{array}$ & \\
\hline & PC3 & $\begin{array}{c}\text { My } \\
\text { knowledge on } \\
\text { IoT based } \\
\text { library } \\
\text { management } \\
\text { systems is } \\
\text { sufficient to } \\
\text { understand the } \\
\text { features of } \\
\text { IoT } \\
\text { applications in } \\
\text { libraries. }\end{array}$ & & 4.26 & $\begin{array}{c}1.0 \\
6\end{array}$ & \\
\hline & PC4 & $\begin{array}{l}\text { I can solve the } \\
\text { problems that } \\
\text { arise due to } \\
\text { implementatio } \\
\mathrm{n} \text { of IoT based }\end{array}$ & & 4.13 & $\begin{array}{l}1.0 \\
2\end{array}$ & \\
\hline
\end{tabular}




\begin{tabular}{|c|c|c|c|c|c|c|}
\hline & & $\begin{array}{l}\text { systems in } \\
\text { libraries. }\end{array}$ & & & & \\
\hline & PC5 & $\begin{array}{c}\text { The } \\
\text { knowledge I } \\
\text { possess from } \\
\text { learning } \\
\text { library } \\
\text { automation } \\
\text { softwares like } \\
\text { LIBSYS, } \\
\text { Koha etc. } \\
\text { enables me to } \\
\text { spend less } \\
\text { time to learn } \\
\text { IoT } \\
\text { applications } \\
\text { such as RFID, } \\
\text { Wi-Fi etc. }\end{array}$ & & 4.38 & $\begin{array}{c}1.2 \\
2\end{array}$ & \\
\hline & PC6 & $\begin{array}{l}\text { I do not have } \\
\text { any } \\
\text { psychological } \\
\text { resistance to } \\
\text { use a new } \\
\text { information } \\
\text { technology. }\end{array}$ & & 5.07 & $\begin{array}{c}1.1 \\
9\end{array}$ & \\
\hline & PC7 & $\begin{array}{c}\text { I have } \\
\text { experience in } \\
\text { using IoT } \\
\text { technologies } \\
\text { like RFID, } \\
\text { cloud } \\
\text { computing } \\
\text { etc. in library } \\
\text { services. }\end{array}$ & & 4.25 & $\begin{array}{c}1.4 \\
3\end{array}$ & \\
\hline & PC8 & $\begin{array}{l}\text { The IoT based } \\
\text { systems such } \\
\text { as RFID, } \\
\text { cloud } \\
\text { computing } \\
\text { and Wi-Fi is } \\
\text { relevant for } \\
\text { the library } \\
\text { users to gain } \\
\text { knowledge. }\end{array}$ & & 4.16 & $\begin{array}{c}1.3 \\
7\end{array}$ & \\
\hline & & AVERAGE & & 4.27 & & \\
\hline \multirow[t]{2}{*}{$\begin{array}{l}\text { PERCEIVED } \\
\text { USEFULNESS }\end{array}$} & PU1 & $\begin{array}{l}\text { Using the IoT } \\
\text { technology } \\
\text { enhances the } \\
\text { efficiency of } \\
\text { library } \\
\text { housekeeping } \\
\text { works. }\end{array}$ & 0.77 & 3.65 & $\begin{array}{l}1.2 \\
8\end{array}$ & 0.85 \\
\hline & PU2 & Using the IoT & & 4.74 & 1.1 & \\
\hline
\end{tabular}


The Application of Tam for Investigating Users' Attitude towards Iot usage in the University Libraries of Odisha

\begin{tabular}{|c|c|c|c|c|c|c|}
\hline & & $\begin{array}{l}\text { technology in } \\
\text { libraries } \\
\text { increase the } \\
\text { library service } \\
\text { productivity. }\end{array}$ & & & 5 & \\
\hline & PU3 & $\begin{array}{l}\text { Using the IoT } \\
\text { applications } \\
\text { enables to do } \\
\text { library works } \\
\text { quickly. }\end{array}$ & & 4.13 & $\begin{array}{l}1.1 \\
7\end{array}$ & \\
\hline & PU4 & $\begin{array}{l}\text { IoT based } \\
\text { system } \\
\text { interfaces } \\
\text { enhances my } \\
\text { effectiveness } \\
\text { in my job. }\end{array}$ & & 4.25 & $\begin{array}{c}0.9 \\
9\end{array}$ & \\
\hline & PU5 & $\begin{array}{l}\text { I could } \\
\text { recover from } \\
\text { mistakes } \\
\text { quickly and } \\
\text { easily over the } \\
\text { IoT based } \\
\text { library } \\
\text { integrated } \\
\text { system. }\end{array}$ & & 3.55 & $\begin{array}{c}1.4 \\
2\end{array}$ & \\
\hline & PU6 & $\begin{array}{l}\text { I found the } \\
\text { IoT based } \\
\text { library } \\
\text { interfaces to } \\
\text { be flexible to } \\
\text { interact with. }\end{array}$ & & 4.76 & $\begin{array}{c}1.3 \\
7\end{array}$ & \\
\hline & PU7 & $\begin{array}{l}\text { I could use the } \\
\text { IoT based } \\
\text { library } \\
\text { resources } \\
\text { without } \\
\text { written } \\
\text { instructions. }\end{array}$ & & 4.64 & $\begin{array}{c}1.2 \\
9\end{array}$ & \\
\hline & PU8 & $\begin{array}{l}\text { I could use the } \\
\text { IoT } \\
\text { technology in } \\
\text { library system } \\
\text { successfully } \\
\text { every time. }\end{array}$ & & 4.28 & $\begin{array}{l}1.2 \\
2\end{array}$ & \\
\hline & & AVERAGE & & 4.25 & & \\
\hline $\begin{array}{l}\text { PERCEIVED EASE } \\
\text { OF USE }\end{array}$ & $\begin{array}{c}\text { PEU } \\
1\end{array}$ & $\begin{array}{c}\text { IoT } \\
\text { applications } \\
\text { are easy to use } \\
\text { than installing } \\
\text { software in } \\
\text { desktop } \\
\text { computing. }\end{array}$ & 0.89 & 5.12 & $\begin{array}{c}1.2 \\
6\end{array}$ & 0.77 \\
\hline
\end{tabular}




\begin{tabular}{|c|c|c|c|c|c|c|}
\hline & $\begin{array}{c}\text { PEU } \\
2\end{array}$ & $\begin{array}{c}\text { IoT } \\
\text { applications } \\
\text { are foolproof } \\
\text { operations and } \\
\text { do not require } \\
\text { skills. }\end{array}$ & & 4.36 & $\begin{array}{c}1.0 \\
8\end{array}$ & \\
\hline & $\begin{array}{c}\text { PEU } \\
3\end{array}$ & $\begin{array}{c}\text { IoT } \\
\text { applications } \\
\text { are easy to } \\
\text { handle } \\
\text { painless and } \\
\text { less bothering. }\end{array}$ & & 4.45 & $\begin{array}{c}1.1 \\
1\end{array}$ & \\
\hline & $\begin{array}{c}\text { PEU } \\
4\end{array}$ & $\begin{array}{c}\text { IoT } \\
\text { applications } \\
\text { are } \\
\text { customizable } \\
\text { and } \\
\text { interactive. } \\
\end{array}$ & & 4.24 & $\begin{array}{c}1.3 \\
2\end{array}$ & \\
\hline & $\begin{array}{c}\text { PEU } \\
5\end{array}$ & $\begin{array}{c}\text { IoT } \\
\text { applications } \\
\text { can be used on } \\
\text { any system } \\
\text { with network } \\
\text { connectivity. }\end{array}$ & & 3.79 & $\begin{array}{c}1.2 \\
8\end{array}$ & \\
\hline & $\begin{array}{c}\text { PEU } \\
6\end{array}$ & $\begin{array}{c}\text { Using IoT } \\
\text { applications in } \\
\text { library would } \\
\text { not lead to } \\
\text { technical } \\
\text { difficulties in } \\
\text { my } \\
\text { organization. }\end{array}$ & & 4.37 & $\begin{array}{c}1.1 \\
7\end{array}$ & \\
\hline & $\begin{array}{c}\text { PEU } \\
7\end{array}$ & $\begin{array}{c}\text { IoT } \\
\text { technology } \\
\text { integrates } \\
\text { quite easily in } \\
\text { our library } \\
\text { infrastructure. }\end{array}$ & & 4.18 & $\begin{array}{c}1.3 \\
5\end{array}$ & \\
\hline & $\begin{array}{c}\text { PEU } \\
8\end{array}$ & $\begin{array}{l}\text { It would be } \\
\text { easy for me to } \\
\text { become } \\
\text { skillful at } \\
\text { using the IoT } \\
\text { in library } \\
\text { services. }\end{array}$ & & 4.64 & $\begin{array}{c}1.1 \\
2\end{array}$ & \\
\hline & & AVERAGE & & 4.39 & & \\
\hline ATTITUDE & ATI1 & $\begin{array}{c}\text { I had a } \\
\text { generally } \\
\text { favourable } \\
\text { attitude } \\
\text { towards using } \\
\text { the IoT } \\
\text { technologies }\end{array}$ & 0.85 & 4.08 & $\begin{array}{c}1.2 \\
9\end{array}$ & 0.816 \\
\hline
\end{tabular}


The Application of Tam for Investigating Users' Attitude towards Iot usage in the University Libraries of Odisha

\begin{tabular}{|c|c|c|c|c|c|c|}
\hline & & $\begin{array}{c}\text { in library } \\
\text { system. }\end{array}$ & & & & \\
\hline & ATI2 & $\begin{array}{l}\text { It provides } \\
\text { integrated, } \\
\text { timely and } \\
\text { reliable } \\
\text { information. }\end{array}$ & & 4.35 & $\begin{array}{c}1.1 \\
8\end{array}$ & \\
\hline & ATI3 & $\begin{array}{l}\text { Using IoT } \\
\text { applications in } \\
\text { library } \\
\text { services is } \\
\text { beneficial. }\end{array}$ & & 4.17 & $\begin{array}{c}1.3 \\
0\end{array}$ & \\
\hline & ATI4 & $\begin{array}{c}\text { IoT usage } \\
\text { provides } \\
\text { access to most } \\
\text { data. }\end{array}$ & & 3.66 & $\begin{array}{c}1.1 \\
4\end{array}$ & \\
\hline & ATI5 & $\begin{array}{l}\text { Adoption of } \\
\text { IoT } \\
\text { technology } \\
\text { provides } \\
\text { accurate } \\
\text { information. } \\
\end{array}$ & & 4.22 & $\begin{array}{c}1.2 \\
3\end{array}$ & \\
\hline & ATI6 & $\begin{array}{l}\text { I believe it is a } \\
\text { good idea to } \\
\text { use IoT } \\
\text { technologies } \\
\text { in libraries for } \\
\text { smooth } \\
\text { functioning of } \\
\text { it. }\end{array}$ & & 4.46 & $\begin{array}{c}1.4 \\
6\end{array}$ & \\
\hline & & AVERAGE & & 4.15 & & \\
\hline \multirow[t]{2}{*}{$\begin{array}{c}\text { BEHAVIORAL } \\
\text { INTENTION TO } \\
\text { USE IOT } \\
\text { TECHNOLOGY } \\
\text { IN LIBRARIES }\end{array}$} & BI1 & $\begin{array}{c}\text { My } \\
\text { organization } \\
\text { has an } \\
\text { intention to } \\
\text { participate in } \\
\text { IoT } \\
\text { development } \\
\text { programme } \\
\text { for its } \\
\text { implementatio } \\
\mathrm{n} \text { in libraries. }\end{array}$ & 0.80 & 4.39 & $\begin{array}{c}1.0 \\
2\end{array}$ & 0.79 \\
\hline & $\mathrm{BI} 2$ & $\begin{array}{c}\text { I am willing to } \\
\text { use IoT } \\
\text { applications } \\
\text { such as RFID, } \\
\text { Cloud } \\
\text { computing } \\
\text { and Wi-Fi in } \\
\text { libraries to } \\
\text { improve my } \\
\text { job }\end{array}$ & & 4.15 & $\begin{array}{c}1.2 \\
2\end{array}$ & \\
\hline
\end{tabular}




\begin{tabular}{|c|c|c|c|c|c|c|}
\hline & & $\begin{array}{l}\text { performance } \\
\text { in future. }\end{array}$ & & & & \\
\hline & $\mathrm{BI} 3$ & $\begin{array}{l}\text { Assuming that } \\
\text { I had access to } \\
\text { IoT } \\
\text { technology, I } \\
\text { intend to use } \\
\text { it. }\end{array}$ & & 3.39 & $\begin{array}{l}1.2 \\
7\end{array}$ & \\
\hline & BI4 & $\begin{array}{c}\text { I have an } \\
\text { intention to } \\
\text { take time to } \\
\text { learn how to } \\
\text { use IoT. }\end{array}$ & & 4.26 & $\begin{array}{c}1.3 \\
4\end{array}$ & \\
\hline & BI5 & $\begin{array}{l}\text { The library is } \\
\text { planning to } \\
\text { introduce IoT } \\
\text { applications in } \\
\text { the libraries in } \\
\text { near future. }\end{array}$ & & 4.73 & $\begin{array}{c}1.0 \\
9\end{array}$ & \\
\hline & BI6 & $\begin{array}{l}\text { Our library } \\
\text { has an } \\
\text { intention to } \\
\text { recommend } \\
\text { IoT usage to } \\
\text { other libraries } \\
\text { in the state } \\
\text { that we have a } \\
\text { cooperative } \\
\text { relationship } \\
\text { with. }\end{array}$ & & 4.48 & $\begin{array}{c}1.1 \\
4\end{array}$ & \\
\hline & $\mathrm{BI} 7$ & $\begin{array}{l}\text { The library } \\
\text { expects the } \\
\text { information } \\
\text { provided by } \\
\text { the new IoT } \\
\text { based system } \\
\text { to be useful.. }\end{array}$ & & 4.61 & $\begin{array}{c}1.2 \\
5\end{array}$ & \\
\hline & & AVERAGE & & 4.28 & & \\
\hline \multirow[t]{3}{*}{$\begin{array}{l}\text { ACTUAL USE OF IOT } \\
\text { IN LIBRARIES }\end{array}$} & AU1 & $\begin{array}{l}\text { I use the IoT } \\
\text { based library } \\
\text { system } \\
\text { frequently. }\end{array}$ & 0.74 & 4.55 & $\begin{array}{c}1.3 \\
9\end{array}$ & 0.83 \\
\hline & AU2 & $\begin{array}{c}\text { I always try } \\
\text { IoT } \\
\text { applications in } \\
\text { libraries in as } \\
\text { many cases as } \\
\text { possible. }\end{array}$ & & 4.12 & $\begin{array}{c}0.9 \\
8\end{array}$ & \\
\hline & AU3 & $\begin{array}{l}\text { I intend to use } \\
\text { IoT based } \\
\text { sevice to } \\
\text { assist my } \\
\text { tasks. }\end{array}$ & & 3.88 & $\begin{array}{l}1.1 \\
7\end{array}$ & \\
\hline
\end{tabular}


The Application of Tam for Investigating Users' Attitude towards Iot usage in the University Libraries of Odisha

\begin{tabular}{|l|l|l|l|l|l|l|}
\hline & AU4 & $\begin{array}{c}\text { I always try } \\
\text { IoT } \\
\text { technology to } \\
\text { conduct a job } \\
\text { whenever it } \\
\text { has a feature } \\
\text { to help me to } \\
\text { perform it. }\end{array}$ & & 4.37 & 1.0 & 6 \\
AVERAGE & & 4.23 & & \\
\hline
\end{tabular}

As shown in table-5, the means of the items range from 3.39 to 5.12, while the average mean of the constructs vary from 4.08 to 4.62. Standard deviations of all items range from 0.75 to 1.46 , indicating a fairly narrow spread of scores around the means. CR coefficients confirm that all the constructs have great internal consistency as they present values between 0.74 and 0.89 , which are well above the minimum required level of 0.7 . The average variance extracted (AVE) is suggested to be 0.50 or higher for an indication of adequate convergence. The AVE falls between 0.769 and 0.92 , as shown in Table-5. This means that there is a strong convergent validity for the set of latent variables and corresponding items in the measurement model. We can therefore conclude that the convergent validity for the proposed constructs of the measurement model was adequate for structural equation modeling.

\subsubsection{Assessing Discriminant Validity}

The discriminant validity of the measurement model was examined through the comparison of the square root of AVE of each construct to the correlations between the latent variables. The average shared variances and the correlation coefficients of latent variables are summarized in table-6.

Table 6 Discriminant Validity of Principal Constructs

\begin{tabular}{|c|c|c|c|c|c|c|c|c|c|}
\hline & OC & TF & EF & PC & PU & PEU & ATI & BI & AU \\
\hline OC & $\mathbf{0 . 9 1 6}$ & & & & & & & & \\
\hline TF & 0.26 & $\mathbf{0 . 8 7}$ & & & & & & & \\
\hline EF & 0.52 & 0.25 & $\mathbf{0 . 9 0}$ & & & & & & \\
\hline PC & 0.69 & 0.37 & 0.39 & $\mathbf{0 . 8 6}$ & & & & & \\
\hline PU & 0.29 & 0.20 & 0.15 & 0.26 & $\mathbf{0 . 8 9}$ & & & & \\
\hline PEU & -0.09 & 0.06 & 0.08 & 0.05 & 0.33 & $\mathbf{0 . 8 4}$ & & & \\
\hline ATI & 0.40 & 0.30 & 0.23 & -0.12 & 0.17 & 0.21 & $\mathbf{0 . 9 0}$ & & \\
\hline BI & 0.62 & 0.15 & 0.01 & 0.59 & 0.31 & 0.49 & 0.18 & $\mathbf{0 . 8 8}$ & \\
\hline AU & -0.08 & 0.32 & 0.34 & 0.08 & -0.02 & 0.00 & 0.15 & 0.54 & $\mathbf{0 . 8 5}$ \\
\hline
\end{tabular}

$* \mathrm{p}<0.05, * * \mathrm{p}<0.01$

Diagonal entries in bold: Square root of average variance extracted; Off-diagonal entries: correlations between constructs

Since all constructs have AVE greater than 0.5 and the diagonal elements(in bold) greater than correlation values in the respective corresponding rows or columns, the results implies that the discriminant validity is supported. It also shows that almost all variables have a statistically significant correlation and since the correlation coefficients aren't 0.7 or higher, there is no multicollinearity. Therefore, the results of convergent validity and discriminant validity are sufficient to support the construct validity of the measurement scales in this study. 


\subsubsection{Structural equation modeling (SEM)}

SEM is a multivariate technique is assessed by examining the structural model fit and the standardized path coefficients to find out if the hypothesized relationships are supported or not. This study assesses overall model fit using the nine indices of absolute fit and incremental fit.

Table 7 Goodness-of-fit indices for SEM of research model

\begin{tabular}{|c|c|c|c|c|}
\hline Fit Indices & $\begin{array}{c}\text { Recommended } \\
\text { Value }\end{array}$ & $\begin{array}{c}\text { Measurement } \\
\text { Model }\end{array}$ & $\begin{array}{c}\text { Structural } \\
\text { Model }\end{array}$ & $\begin{array}{c}\text { Determination of } \\
\text { Model Fitness }\end{array}$ \\
\hline$\chi^{\mathbf{2}}$ & N/A & 1299.4 & 1298.6 & \\
\hline $\mathrm{df}$ & N/A & 611.00 & 610.0 & Fit \\
\hline$\chi^{\mathbf{2}} / \mathrm{df}$ & $\leq 3.0$ & 2.64 & 2.62 & Fit \\
\hline GFI & $\geq 0.8$ & 0.91 & 0.91 & Fit \\
\hline AGFI & $\geq 0.8$ & 0.89 & 0.89 & Fit \\
\hline CFI & $\geq 0.9$ & 0.96 & 0.95 & Fit \\
\hline NFI & $\geq 0.9$ & 0.90 & 0.93 & Fit \\
\hline NNFI & $\geq 0.9$ & 0.95 & 0.96 & Fit \\
\hline RMSEA & $\leq 0.08$ & 0.06 & 0.07 & Fit \\
\hline RMSR & $\leq 0.10$ & 0.05 & 0.06 & Fit \\
\hline RFI & $0 \sim 1$ & 0.05 & 0.06 & \\
\hline
\end{tabular}

The overall fit of the measurement model was assessed based on various set of commonly used fit indices. The ratio of $\chi^{2}$ to degree-of-freedom was $2.62\left(\chi^{2}=1298.6, \mathrm{df}=610\right)$ for the structural model and 2.64 for the measurement model, which is lower than 3 indicating an acceptable fit. The Goodness-of-Fit (GFI) and Adjusted Goodness-of-fit (AGFI) were 0.91 and 0.89 respectively for both the structural model as well as measurement model. The Normalized fit index (NFI), Non-Normalized fit Index(NNFI) and comparative fit index(CFI) values for the structural model is $0.93,0.96$ and 0.95 while we observe values of $0.90,0.95$ and 0.96 for the measurement model respectively. All these values indicate good model fit for the above variables/model.

Finally, the Root Mean Square Residual (RMSR) was obtained 0.06, whereas Root Mean square error of approximation (RMSEA) has 0.07 for the structural model and $0.05 \& 0.06$ for the measurement model respectively. Both the values are within the recommended cutoff values of 0.10 (RMSR) and 0.08 (RMSEA) for goodness of fit. Therefore, we proceed to examine the path coefficients of the structural model.

\subsubsection{Hypothesis Testing}

Structural model is used to test a theoretical model by presenting the model's constructs with their dependence relationships. These relationships link exogenous variables with endogenous variables presented with one-headed arrow. During this stage, the hypotheses are tested to find whether they obey the established relationships between the various constructs of the proposed research model. The hypotheses are tested by regressing both four external factors as independent and five TAM variables as dependent variables. The test also produces the squared multiple correlations $\left(\mathrm{R}^{2}\right)$, which indicates the variance of the dependent constructs.Table- 8 presents the equations with standardized path coefficients $(\beta)$ for the hypothesized research model, along with the $\mathrm{R}^{2}$ value for the endogenous variables. The $\beta$ value indicates the strengths of the relationships between the independent and dependent variables. The significance measure was used to determine the level of inclination the dependent constructs have towards the acceptance and usage of IoT applications in library 
services. This was done by using the t-ratio test statistics on the dependent constructs and the results are summarized in table- 8 . Based on the values of the standardized path coefficients $(\beta)$ and corresponding t-values each of the hypotheses is either supported or rejected.

Table 8 Empirical results of Hypotheses Testing

\begin{tabular}{|c|c|c|c|c|c|c|}
\hline Hypothesis & Path & $\begin{array}{c}\text { Path-coefficient } \\
\text { Standardized } \\
\text { coefficients( } \boldsymbol{\beta})\end{array}$ & p-value & t-value & $\mathbf{R}^{2}$ & Result \\
\hline $\mathrm{H} 1 \mathrm{a}$ & OC $\rightarrow$ PU & $0.275^{* *}$ & $0.30^{*}$ & $5.32^{* * *}$ & 0.76 & yes \\
\hline $\mathrm{H} 1 \mathrm{~b}$ & OC $\rightarrow$ PEU & $0.143^{* * *}$ & $0.58^{* *}$ & $2.66^{* *}$ & 0.882 & yes \\
\hline $\mathrm{H} 2 \mathrm{a}$ & $\mathrm{TF} \rightarrow \mathrm{PU}$ & $0.026^{* *}$ & $0.19^{*}$ & $3.37^{* * *}$ & 0.69 & yes \\
\hline $\mathrm{H} 2 \mathrm{~b}$ & $\mathrm{TF} \rightarrow \mathrm{PEU}$ & $0.332^{* * *}$ & $0.18^{* * *}$ & $6.14^{* * *}$ & 0.777 & yes \\
\hline $\mathrm{H} 3 \mathrm{a}$ & $\mathrm{PC} \rightarrow \mathrm{PU}$ & $0.197^{*}$ & $0.09^{* *}$ & $5.58^{* *}$ & 0.71 & yes \\
\hline $\mathrm{H} 3 \mathrm{~b}$ & $\mathrm{PC} \rightarrow \mathrm{PEU}$ & 0.36 & 0.14 & -1.594 & 0.568 & No \\
\hline $\mathrm{H} 4 \mathrm{a}$ & $\mathrm{EF} \rightarrow \mathrm{PU}$ & 0.61 & 0.36 & 1.01 & 0.601 & No \\
\hline $\mathrm{H} 4 \mathrm{~b}$ & $\mathrm{EF} \rightarrow \mathrm{PEU}$ & $0.289^{* *}$ & $0.50^{*}$ & $4.31^{* *}$ & 0.75 & Yes \\
\hline $\mathrm{H} 5 \mathrm{a}$ & $\mathrm{PEU} \rightarrow \mathrm{PU}$ & $0.568^{* * *}$ & $0.44^{*}$ & $3.46^{* * *}$ & 0.862 & Yes \\
\hline $\mathrm{H} 5 \mathrm{~b}$ & $\mathrm{PEU} \rightarrow \mathrm{BI}$ & 0.112 & 0.40 & -1.39 & 0.719 & No \\
\hline $\mathrm{H} 6 \mathrm{a}$ & $\mathrm{PU} \rightarrow \mathrm{ATI}$ & $0.338^{* * *}$ & $0.39^{*}$ & $2.96^{*}$ & 0.9 & yes \\
\hline $\mathrm{H} 6 \mathrm{~b}$ & $\mathrm{PU} \rightarrow \mathrm{BI}$ & $0.676^{* *}$ & $0.154^{* *}$ & $4.414^{*}$ & 0.635 & yes \\
\hline $\mathrm{H} 7$ & $\mathrm{ATI} \rightarrow \mathrm{BI}$ & 0.554 & 0.062 & -2.107 & 0.559 & No \\
\hline $\mathrm{H} 8$ & $\mathrm{BI} \rightarrow \mathrm{AU}$ & $0.796^{* * *}$ & $0.087^{* *}$ & $3.823^{*}$ & 0.844 & Yes \\
\hline
\end{tabular}

$* p<0.05 ; * * p<0.01 ; * * * p<0.001$

The estimation result of the model consists of properties of the casual paths including standardized path coefficients, $t$-values, $p$-value and variance explained for each equation in the hypothesized model are summarized below:-

- H1a (OC $\rightarrow$ PU): Based on the result shown in table-8, organizational factor has a significant positive influence on user's perceived usefulness $(\beta=0.275, p<0.01)$ resulting in $\mathrm{R} 2$ of 0.77 .This value suggests that organizational competency accounted for $77 \%$ of the variance related to PU towards the usage of IoT in libraries. The t-value is 5.32 which are significant at $\mathrm{p}<0.05$ level. Therefore, the hypothesis H1a is supported.

- H1b (OC $\rightarrow$ PEU): Organizational factor has a significant positive impact on user's perceived ease of use $(\beta=0.143, p<0.001)$ resulting in $\mathrm{R} 2$ of 0.882 , which means OC accounted for $88 \%$ of the variance in PEU. Therefore, the hypothesis H1b is supported. The $\mathrm{t}$-value is 2.66 which is also significant at $\mathrm{p}<0.05$ level.

- $\mathrm{H} 2 \mathrm{a}(\mathrm{TF} \rightarrow \mathrm{PU}):$ Technological factor has a significant positive impact on user's perceived usefulness $(\beta=0.026, p<0.001)$, resulting in $\mathrm{R} 2$ of 0.69 . It means that TF accounted for a $69 \%$ of the variance in PU. The $\mathrm{t}$-value is 3.37 which is significant at $\mathrm{p}<0.05$ level. Hence the hypothesis $\mathrm{H} 2 \mathrm{a}$ is supported.

- $\mathrm{H} 2 \mathrm{~b}(\mathrm{TF} \rightarrow \mathrm{PEU})$ : Technological factor has a significant positive impact on user's perceived ease of use $(\beta=0.332, p<0.001)$, resulting in $R 2$ of 0.77 . The t-value is 6.14 which is significant at $\mathrm{p}<0.05$ level. The $\mathrm{R} 2$ value suggests that $\mathrm{TF}$ accounted for a $77 \%$ of the variance in PEU. Therefore, $\mathrm{H} 2 \mathrm{~b}$ is supported.

- H3a (PC $\rightarrow$ PU): Personal competency has a significant positive impact on user's perceived usefulness $(\beta=0.197, \mathrm{p}<0.05)$, resulting in $\mathrm{R} 2$ of 0.71 . It means that $\mathrm{PC}$ 
accounted for a $71 \%$ of the variance in PU. The $\mathrm{t}$-value is 5.58 which is significant at $\mathrm{p}<0.05$ level. Therefore, the hypothesis $\mathrm{H} 3 \mathrm{a}$ is supported.

- $\mathrm{H} 3 \mathrm{~b}$ (PC $\rightarrow$ PEU): Personal competency does not have a significant impact on user's perceived ease of use, failing to support the hypothesis $\mathrm{H} 3 \mathrm{~b}(\beta=0.36$, $\mathrm{p}<0.01)$. The R2 value is 0.568 which means PC accounted for a $56 \%$ of the variance on PEU. The t-value is -1.594 which is not significant at $\mathrm{P}<0.05$ level. Therefore, the hypothesis $\mathrm{H} 3 \mathrm{~b}$ is rejected.

- H4a (EF $\rightarrow$ PU): Environmental factor does not have a significant positive influence on user's perceived usefulness, failing to support the hypothesis $\mathrm{H} 4 \mathrm{a}$. The coefficient of correlation $(\beta)$ has the value 0.61 which is insignificant at $\mathrm{p}<0.05$ level. The $\mathrm{t}$-value is 1.01 which also has no significance at $\mathrm{p}<0.05$ level. Hence the hypothesis $\mathrm{H} 4 \mathrm{a}$ is rejected.

- The R2 value was 0.601 suggesting EF accounted for a $60 \%$ of the variance in PU.

- H4b (EF $\rightarrow$ PEU): Environmental factor has a significant positive impact on Perceived ease of uses of the users $(\beta=0.289, p<0.01)$, resulting in $\mathrm{R} 2$ of 0.75 . It means that EF accounted for a $75 \%$ of the variance in PEU. The t-value is 4.31 which is significant at $\mathrm{p}<0.05$ level. Therefore, the hypothesis $\mathrm{H} 4 \mathrm{~b}$ is supported

- H5a (PEU $\rightarrow$ PU): Users' perceived ease of use has a significant influence on user's perceived usefulness $(\beta=0.568, p<0.001)$. The $R 2$ value is 0.862 suggesting that PEU accounted for an $86 \%$ of the variance in PU. The t-value is 3.46 which is significant at $\mathrm{p}<0.01$ level. Therefore, H5a is supported.

- H5b (PEU $\rightarrow$ BI): From the results as shown in table-8, the perceived ease of use of users have no significant impact on behavioral intension towards using IoT in libraries, failing to support hypothesis $H 5 b(\beta=0.112, p<0.05)$. The $R 2$ value was 0.719 which means PEU accounted for a $71 \%$ of the variance in BI. The t-value is -1.39 which shows no significance at $\mathrm{p}<0.05$ level. Therefore, H5b is not supported.

- H6a (PU $\rightarrow$ AT): Users' perceived usefulness has a significant positive impact on users' attitude towards using IoT in libraries $(\beta=0.338, \mathrm{p}<0.001)$ resulting in $\mathrm{R} 2$ of 0.9. It means that PU accounted for a $90 \%$ of the variance in AT. The $t$-value is 2.96 which is significant at $\mathrm{p}<0.5$ level. Therefore, the hypothesis $\mathrm{H} 6 \mathrm{a}$ is supported.

- H6b (PU $\rightarrow \mathrm{BI})$ : The result shows that perceived usefulness of users towards using IoT in libraries have a significant influence on behavioral intension $(\beta=0.676$, $\mathrm{p}<0.01)$. The R2 value was 0.635 which means that PU accounted for a $63 \%$ of the variance in BI. The t-value is 4.414 showing significance at $p<0.05$ level. Hence, the hypothesis H6b is supported.

- H7 (AT $\rightarrow \mathrm{BI})$ : User's attitude towards using IoT in library does not give a significant positive impact on user's behavior intension to use, failing to support hypothesis H7. The coefficient of correlation $(\beta)$ has the value 0.554 which is insignificant at $\mathrm{p}<0.05$ level. The $\mathrm{R} 2$ value is 0.559 , which suggests that AT accounted for a $55 \%$ variance in BI. The $\mathrm{t}$-value is -2.107 which is not significant at $\mathrm{p}<0.05$ level. Therefore, the hypothesis $\mathrm{H} 7$ is rejected.

- H8 (BI $\rightarrow \mathrm{AU})$ : Users' behavioral intension towards using IoT have a significant positive influence on actual use of IoT in libraries $(\beta=0.796, p<0.001)$ resulting in $\mathrm{R} 2$ of 0.844 . The t-value is 3.823 which is significant at $\mathrm{p}<0.05$ level. The R2 
value suggests that BI accounted for an $84 \%$ of the variance in AU. Therefore, the hypothesis $\mathrm{H} 8$ is supported.

From the analysis of the result in table- 8 shows that 10 out of fourteen hypotheses are supported. To the contrary, $\mathrm{H} 3 \mathrm{~b}, \mathrm{H} 4 \mathrm{a}, \mathrm{H} 5 \mathrm{a}$ and $\mathrm{H} 7$ are not supported. If the t-value is greater than 1.96 i.e. (t-value $>1.96$ ), then the coefficients between variables are statistically significant. From the table above, it is shown that Personal competency does not have a significant influence on PEU ( $t$-value $=-1.594<1.96$ ). Similarly, the path coefficient $\mathrm{t}$-values for paths environmental factor to perceived usefulness $(t=1.01)$, perceived ease of use to behavioral intension $(\mathrm{t}=-1.39)$ and attitude to behavioral intension $(\mathrm{t}=-2.107)$, were still below the recommended cutoff point of 1.96 in absolute value. Hence, these hypotheses are not significant. Fig-2 shows the path analysis and path coefficients representing regression weight or coefficients of correlation between two variables. As shown in fig- 2 the significant paths are depicted by bold lines and insignificant paths by dash lines.

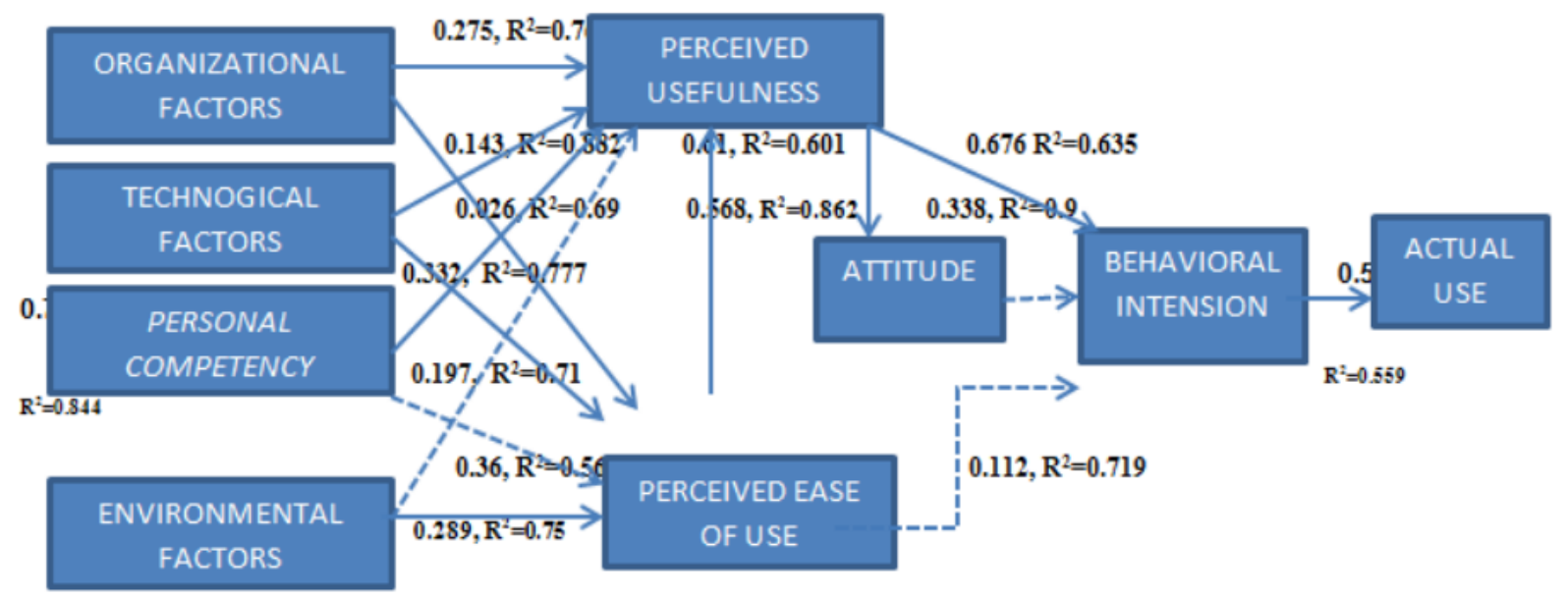

Figure 2 Path Diagram for the Research Model

From the path diagram of the structural model, it indicates that the path values of $\mathrm{H} 1 \mathrm{a}$, H1b, H2a, H2b, H3a, H4b, H5a, H6a, H6b, H8 are 0.275, 0.143, 0.026, 0.332, 0.197, 0.289, $0.568,0.338,0.676$ and 0.796 respectively which all are reaching the level of significance. Hence these are represented as thick lines with their path coefficients, whereas H3b, H4a, $\mathrm{H} 5 \mathrm{~b}, \mathrm{H} 7 \mathrm{are}$ having path values of $0.36,0.61,0.112,0.554$ which are insignificant. Hence, these are represented as thin lines with their path coefficients.

\section{DISCUSSION \& CONCLUSION}

With increased use of IoT technology in libraries, there is a need to understand users' acceptance of IoT in library services and identify the factors that influence their intension to use in the university libraries of Odisha. Therefore the main purpose of this study was to provide valuable insights into the total none factors i.e. four external factors, two internal and three acceptance factors that have significant effects through the TAM framework on participating library users' attitude towards the use of IoT technologies such as RFID, Cloud computing and Wi-Fi in the university libraries of Odisha. This study not only verifies that the TAM can be deployed to explain and predict IoT acceptance but also derived a research model specifying key drivers of library users' behavioural intention towards IoT adoption in library services in Universities of Odisha. Since all the four external variables included in TAM model of this paper were found to have direct or indirect influence on perceived usefulness and perceived ease of use, we can assert that they also affect the attitude and 
behavioral intension of adopting IoT in university libraries of Odisha in future. Further, behavioral intension of the users of university libraries itself affects actual use of IoT technology in these libraries. Thus, the finding of the study shows that there is a positive support of using IoT technology in library integrated systems. The Universities in Odisha promote the adoption of IoT technology by increasing the awareness among students, research scholars, faculties and library professionals about the flexibility and ease of use of new technologies in library. Therefore, the acceptance strategy for implementing IoT in libraries includes the following:

$>$ Availability and quality of the service

$>$ Reputation of the service provider

$>$ Perceived fairness of the price

$>$ Non-intrusiveness of the service, privacy preservation and data security

$>$ Perceived control over devices, services and personal data

$>$ Providing necessary resources such as time, space, equipment and people

\section{REFERENCES}

[1] Atzori, L., Iera, A., Morabito, G., 2010. "The Internet of Things: A survey”. Computer Networks, 54(15): 2787-2805.

[2] Al-Ammary, J. H., Al-Sherooqi, A. K., \& Al-Sherooqi, H. K.2014.”The Acceptance of Social Networking as a Learning Tools at University of Bahrain". International Journal of Information and Education Technology, 4 (2): 208-214. DOI: 10.7763/IJIET.2014.V4.400

[3] Ajzen, I. 2001." Nature and operation of attitudes", Annual Review of Psychology, 52(1): 27-58.

[4] Cunningham, M.S. 2010. "A case study into the implementation of RFID at the Pilkington Library Loughborough University. Loughborough University. A Master's Dissertation, 62p. https://dspace.lboro.ac.uk/dspace-jspui/bitstream/2134/8820/1/MAdissertationCunningham.pdf

[5] Davis, F. D., Bagozzi, R. P., \& Warshaw, P. R. 1989. "User acceptance of computer technology: a comparison of two theoretical models". Management Science, 35: 9821003.

[6] Dwivedi, Y.K., Kapoor, K.K., Williams, M.D and Williams, J. 2013, "RFID systems in libraries: an empirical examination of factors affecting system use and user satisfaction", International Journal of Information Management, 33(2):367-377.

[7] Emmett, D. J. 2011." Student engagement with an ePortfolio: A case study of pre-service education students" The Queensland University of Technology. Retrieved from:http://eprints.qut.edu.au/40957/1/David_Emmett_Thesis.pdf

[8] Davis, F.D. 1989. "Perceived usefulness, perceived ease of use, and user acceptance of information technology". MIS Quarterly, 13(3).

[9] Dholakia, R.R. and Kshetri, N. 2004, "Factors impacting the adoption of the internet among SMEs", Small Business Economics, 23:311-22.

[10] Hong, W. and Zhu, K. 2006, "Migrating to internet-based e-commerce: factors affecting e-commerce adoption and migration at the firm level", Information \& Management, 43: 204-21.

[11] Kranenburg, R.V., 2008. "The Internet of Things: A Critique of Ambient Technology and the All-Seeing Network of RFID”, Institute of Network Cultures.

[12] Kuan, K.K.Y. and Chau, P.Y.K. 2001, "A perception based model for EDI adoption in small business using a technology-organization-environment framework", Information \& Management, 38:507-12. 
The Application of Tam for Investigating Users' Attitude towards Iot usage in the University Libraries of Odisha

[13] Lee, S. and Kim, K. 2007. "Factors affecting the implementation success of internet-based information systems", Computers in Human Behavior, 23: 1853-80.

[14] Luis M. Vaquero1, Luis Rodero-Merino1, Juan Caceres1, Maik Lindner .2009.”A Break in the Clouds: Towards a Cloud Definition", ACM SIGCOMM Computer Communication Review; 39(1):50-55.

[15] Liu, I. F., Chen, M. C., Sun, Y. S., Wible, D., \& Kuo, C. H. 2010. "Extending the TAM model to explore the factors that affect Intention to Use an Online Learning Community". Computers\& Education, 54 (2): 600-610.

[16] Miller, M. 2008." Cloud computing: Web-based applications that change the way you work and collaborate online". Published August 11, 2008 by Que.

[17] Margam Madhusudhan 2010.” RFID technology implementation in two libraries in New Delhi". Program: electronic library and information systems, 44(2):p14.

[18] Oliveira, T., \& Martins, M.F. 2010. "Understanding e-business adoption across industries in European countries. Industrial Management \& Data Systems, 110(9): 1337-1354.

[19] Marchionini, G., Dwiggins, S., Katz, A. and Lin, X. 1993. "Information Seeking in FullText End-User-Oriented Search Systems: The Roles of Domain and Search Expertise", Library and Information Science Research, 15:35-69.

[20] Pyke, J. 2009, "Now is the time to take the cloud seriously", White Paper, available at: www.cordys.com/cordyscms_sites/objects/bb1a0bd7f47b1c91ddf36ba7db88241d/time_to _take_the_cloud_seroiusly_online_1_.pdf.

[21] Pan, M.J. and Jang, W.Y. 2008, "Determinants of the adoption of enterprise resource planning within the technology-organization-environment framework: Taiwan's communications industry”, Journal of Computer Information Systems, 48: 94-102.

[22] H. Son, Y. Park ,C. Kim, and J.-S. Chou,.2012. "Toward an understanding of construction professionals' acceptance of mobile computing devices in South Korea: An extension of the technology acceptance model," Automation in Construction, 28:82-90

[23] Sebastian, S., Ray, P.P., 2015. "Development of IoT invasive architecture for complying with health of home". In: Proceedings of I3CS, Shillong, pp. 79-83.

[24] Sultan, N. 2010. "Cloud computing for education: A new dawn?", International Journal of Information Management, 30:109-116.

[25] Tan, M., \& Teo, T. 2000, "Factors influencing the adoption of Internet banking". Journal of the Association for Information Sciences, 1: 1-42.

[26] Thong, J.Y.L. Hong, W. and Tam, K.Y. 2002. ”Understanding User Acceptance of Digital Libraries: What are the Roles of Interface Characteristics, Organizational Context, and Individual Differences?", International Journal of Human-Computer Studies, 57: 215-242.

[27] Venkatesh, V. \& Davis, F. D. 2000. "A Theoretical Extension of the Technology Acceptance Model: Four longitudinal field studies". Management Science, 46(2):186204.

[28] Wang, Y.M., Wang, Y.S. and Yang, Y.F. 2010, "Understanding the determinants of RFID Adoption in the manufacturing industry", Technological Forecasting \& Social Change, 77: 803-15.

[29] Yang, C.L., B.N. Hwang and B.J.C. Yuan, 2012. "Key consideration factors of adopting cloud computing for science". CloudCom 2012 - Proceedings: 2012 4th IEEE International Conference on Cloud Computing Technology and Science, pp: 597-600.

[30] Zhu, K., Dong, S., Xu, S.X. and Kraemer, K.L. 2006, "Innovation diffusion in global contexts: determinants of post-adoption digital transformation of European companies", European Journal of Information Systems, 15:601-16. 